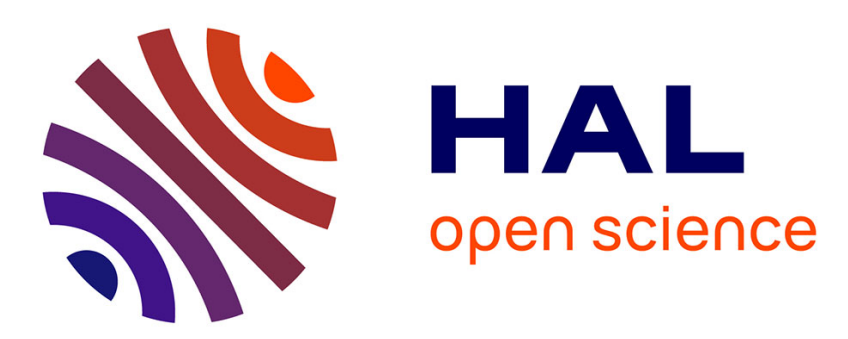

\title{
Stories from the end of the world: in search of plots for a failing system
}

Jerzy Kociatkiewicz, Monika Kostera

\section{To cite this version:}

Jerzy Kociatkiewicz, Monika Kostera. Stories from the end of the world: in search of plots for a failing system. Journal of Organizational Change Management, 2019, 33 (1), pp.66-82. 10.1108/JOCM-022019-0050 . hal-02400920

\section{HAL Id: hal-02400920 \\ https://hal.science/hal-02400920}

Submitted on 12 Nov 2020

HAL is a multi-disciplinary open access archive for the deposit and dissemination of scientific research documents, whether they are published or not. The documents may come from teaching and research institutions in France or abroad, or from public or private research centers.
L'archive ouverte pluridisciplinaire HAL, est destinée au dépôt et à la diffusion de documents scientifiques de niveau recherche, publiés ou non, émanant des établissements d'enseignement et de recherche français ou étrangers, des laboratoires publics ou privés. 


\title{
Stories from the end of the world : In search of plots for a failing system
}

\author{
Jerzy Kociatkiewicz \\ Université Paris-Saclay, Univ Evry, IMT-BS, LITEM, 91025, Evry, France \\ kociak@kociak.org \\ Monika Kostera \\ Jagiellonian Universitym Kraków, Poland \\ monika@kostera.pl
}

\begin{abstract}
The aim of this paper is to consider three types of stories: media, personal accounts and fiction, and look for plots depicting situations of fundamental shift in the framing and basic definitions of reality. We examine them from the point of view of their usefulness for developing creative responses to systemic change. Currently many voices are being raised that we are living in times of interregnum, a period in between working systems. There is also a mounting critique of the business school as an institution perpetuating dysfunctional ideologies, rather than enhancing critical and creative thinking. We propose that the humanities, and, in particular, learning from fiction (and science-fiction) can offer a language to talk about major (systemic) change help and support learning about alternative organizational realities.

The empirical material used for this paper has earlier been the basis for an earlier text with a different aim and slightly different topic: Kociatkiewicz, Jerzy and Monika Kostera (2002) "When reality fails: Science fiction and the fall of communism in Poland." In: Mihaela Kelemen and Monika Kostera (eds.) Managing the Transition: Critical Management Research in Eastern Europe. Palgrave, 217-238.
\end{abstract}

\section{Keywords}

fiction, interregnum, narratives, strong plots, systemic change 


\section{Narratives and the interregnum}

The aim of this paper is to consider three types of stories (media, personal accounts and fiction) and look for plots depicting situations of fundamental shift in the framing and basic definitions of reality. We intend to examine them from the point of view of their usefulness for developing creative responses to systemic change (which, in our opinion, we are currently facing). We discuss the significance of our findings for organizational learning.

Zygmunt Bauman (2012) speaks of our times as marked by dissipation, erosion of structures, as the period of failure of a huge social system. Using the metaphor coined by Antonio Gramsci, he calls our times interregnum, society in between working systems:

The crisis consists precisely in the fact that the old is dying and the new cannot be born; in this interregnum a great variety of morbid symptoms appear (Gramsci, 2005, p. 276).

Bauman describes this period as transitory; however, its length is unknown. We do not know what will follow, and that, in itself, is difficult. To the systemic uncertainty are added other morbid symptoms, such as the concentration of power and wealth, ferocious and accelerating inequality, the real and unprecedented threat to the survival of humanity and the whole planet. Wolfgang Streeck (2016a) speaks of a prolonged social entropy of the interregnum, or the

breakdown of macro-level system integration, depriving individuals at the micro-level of institutional structuring and collective support and shifting the burden of ordering social life, of providing it with a modicum of security and stability, to individual actors and such social arrangements as they can improvise on their own. A society in interregnum, in other words, would be a deinstitutionalised or under-institutionalised society, one in which expectations can be stabilized only now and then by local extemporisation, and which for this very reason is essentially ungovernable (Streeck, 2016b, p. 69).

Social institutions lose legitimacy and social structures crumble. It is difficult if not impossible to engage in constructive projects on a bigger societal scale. Everything seems to be going awry in societies and collaboration has grown difficult. However, power and wealth inequalities not only continue, but increase into proportions unseen since the times of Nero. Cynicism has become a widespread coping mechanism which helps individuals to deal with the mounting feelings of insecurity and meaninglessness but makes the recovery of the system increasingly less likely. Streeck's vision of the interregnum is bleak but far from anarchic. Chris Harman (2009) offers a similar vision, though backed by a different metaphor, writing of zombie capitalism: a global system that continues to function by sinister inertia, because it is so big, lacks an alternative and disdains opposition. It continues to concern humans, organizations, relationships and the planet, but it has lost its vitality, grace and meaning.

It is not surprising that societies, faced with the lack of viable alternatives and searching for a way out of the impasse, turn nostalgically back towards an imaginary past when "things were better" simply because they worked. Zygmunt Bauman (2017) speaks of the retrotopia: a utopia of the past rather than of the future. History is being re-invented and colonized for the use of politicians and other powerful leaders who exploit whatever they can find in an attempt to stabilize and secure even more power. Institutions and structures of the past, from strict borders enforcing sedentary residence to rigid criminal codes promoting moral uprightness are welcomed back in a bid to recreate that vision. This tendency does not, and cannot, offer solutions to the burning problems of today's world. It is impossible to turn back time, not least because of all the unresolved tensions of solid modernity which contributed to its liquidification.

Meanwhile, the management by wreckage, advocated and practiced by transformational organizational bosses as well as by fresh-faced political candidates, undermines whatever is left of legitimacy and hope in social institutions (Fleming, 2017). The ecological costs of this state of things and of the totalizing and perpetuating narratives of "progress" in the face of these costs, pose a real and lethal threat for the majority of human and nonhuman population of the planet (Klein, 2014). Yet there is still no vision of a model ready to replace it (Streeck, 2016a).

This is a powerful narrative of finality, a tale of the end, as in this famous song:

This is the end, beautiful friend, the end [...]

Of our elaborate plans, the end, 
Of everything that stands, the end

No safety of surprise, the end (The Doors, 1967)

It is, however, not the only end we have known. We remember yet another collapse, depicted in Alexei Yurchak's aptly titled book, Everything was forever, until it was no more (2005). The book tells the story of the fall of the Soviet empire, or, rather, of the immortality of the empire. It begins with a quotation from an interview with songwriter Andrei Makarevich:

"It had never even occurred to me that in the Soviet Union anything could ever change. Let alone that it could disappear. No one expected it. Neither children, nor adults. There was a complete impression that everything was forever." (Yurchak, 2006, p. 1)

The system was eternal, even when it was nearing its chronological end it did not occur to its inhabitants (or observers, we may add), that it is collapsing. And yet, the author continues: "although the system's collapse had been unimaginable before it began, it appeared unsurprising when it happened" (ibid., p. 1). People seemed to experience a kind of a "break of consciousness" (ibid., p. 2), a shock followed by a quick transition into a new system, new era and new stories. The change was exciting, exhilarating even, but quite abrupt. What appeared impossible before, now seemed obvious. The stories altered as dramatically: from narratives supporting the everlasting order to tales condemning the regime; from legimitimizing plots to accounts of delegitimization. The aim of Yurchak's book is to give voice to other stories, outside of the narrow function which seems to steer and dominate all storytelling, popular and scientific, pertaining to the fallen system. These stories turn out to be paradoxical: both of an eternal and vigorous system, and of a declining and bleak empire. Authoritative and constative discourse co-existed, sometimes in creative and agentive ways. In the last period of the system's existence, known as perestroika, the authoritative and "transparent" voice was deconstructed and replaced with a sense of "truth" and a venue for a public metacommentary. Yurchak gives space to all these tales and reflects on their significance but does not attempt at (re-)creating the tales of the shift itself: these seem to be too elusive to be told. There is no language for such tales.

In our country of origin the shift was just as dramatic, even though both its history and its further fate are different. Before the fall there was the darkness of the
Martial Law, which was enforced on December 13th, 1981 in Poland, after the Solidarity rebellion that lasted for almost one and a half year. It felt like all hope was being buried forever. The system, once again, proved that it was invincible. The massive popular movement, which had reached 10 million members at its peak, was shattered during the following years; the leaders were, once again, imprisoned, censorship tightened anew, and the people subjected to a new wave of unbearably triumphant propaganda. Its main rhetorical style was named panswinism by Michal Głowiński (1992), with the overriding message that "we are all swine," no one is honest, Party people are swine, but so are the Solidarity people. So are, in fact, all of you. There is no way out.

The system felt, and was, permanent. At the university, among friends and colleagues who distanced themselves from it, one of us heard isolated opinions that it would perhaps end someday. Maybe in 100 years, maybe in 50 . The year was 1983 .

And then, in 1989, the state TV began showing glimpses of remarkable events: so-called „round-table talks”, where representatives of the opposition and Party officials met and discussed possible scenarios for the future. Books, until recently passed on from friend to friend in confidence, were sold from camping tables in the streets. On June 4th, 1989, in the (semi-)free elections after the World War II, opposition candidates celebrated a landslide victory. Later the Berlin Wall fell, more and more countries from behind the once so impenetrable Iron Curtain joined in shaking off a system that was, not so long ago, immortal. We were facing the impossible - the until recently solid institutions and structures were no more. How did that happen? What is happening right now, as we write and speak? How can we know that it is happening and make the best use possible of the creative moment that a systemic change offers? In this paper we propose to learn to tell each other stories, different from the ones we are used to, in order to find a good way out of the chaos of the interregnum. In the words of the "Dark Mountain Manifesto" (2014):

It is time to look for new paths and new stories, ones that can lead us through the end of the world as we know it and out the other side (The Dark Mountain Project, p. 20).

It is vital to start now, as 
The end of the world as we know it is not the end of the world full stop. Together, we will find the hope beyond hope, the paths which lead to the unknown world ahead of us (ibid., p. 31).

\section{Stories}

Since times immemorial humans have been "huddling about the campfire" and telling each other stories, proposes Ursula Le Guin (1980) to share tales false or true:, because it is the most human of all things and it binds us together:

In the tale, in the telling, we are all one blood. (ibid., p. 1999).

Narratives are a natural way of organising human experience and the way in which people perceive the world, and the most basic form of interpersonal communication (Bruner, 1991). They offer structure to human experience and help to orchestrate and share collective action and thus to organize and to talk about organizing (Boje, 2001). Stories are a special kind of "narratives with simple but resonant plots and characters, involving narrative skills, entailing risk, and aiming to entertain, persuade and win over [the listeners]" (Gabriel, 2000, p. 22). Through stories it is possible to gain understanding of complex social processes, such as the processes of organizing, for everyday use as for systemic scientific exploration (Gabriel, 2000). There are strong traditions of story based approaches within social sciences, such as case studies, and more recently studies of organizational stories and various interpretive approaches (Czarniawska-Joerges, 1995). Ultimately, they are a medium of theory and knowledge:

Theories do not "represent" reality; theoreticians take upon themselves to represent other people and even nature" (ibid., p. 27).

To be effective in theory building, organization theory should aim for

a conscious and reflective creation of a specific genre, which recognizes tradition without being paralyzed by it, which seeks inspiration in other genres without imitating them, which derives confidence from the importance of its topic and from its own growing skills (ibid., p. 28).

"Other genres" include, above all, novels. Literature can be a rich source of insight. Pierre Guillet de Monthoux and Barbara Czarniawska-Joerges (1994) present works of fiction from different countries and show how they shed interesting light upon organizational and managerial practices in those countries. The ability of books such as Musil's The Man without Qualities to be persistently enlightening depends on the author's detailed and rigorous research (even though they were not professional researchers), but also on the particular quality of the genre.

Stories of all genres have a special role in social science that aims at a deeper inquiry into levels of culture beyond the purely manifested and momentarily practiced, because

Whatever its presumed motives or traceable effects, and whether it takes a relatively authoritative, monologic form or a more open, dialogic form, narrative is first and foremost a mediating form through which "meaning" must pass. Stories, in other words, are productive. They catch up cultural conventions, relations of authority, and fundamental spatio-temporal orientations in the dense sociality of words and images in use and produce a constant mediation of the "real" in a proliferation of signs, creativity $[\ldots]$, the sense of a surplus of meaning $[\ldots]$ (Stewart, 1996, p. 30)

This does not mean equating social science with literature. Rather, a mutual enlightened conversation, listening, interpreting and understanding. Umberto Eco (2000), a powerful presence in both of these fields, believed in interweaving stories with more disciplined, scientific narration, in order to enhance discourse, to illustrate theses, and to anchor scientific reflections in human experience. All those reasons are valid for our present undertaking, which can be said to be a study of a (very specific) cultural context of organizing organizing (Hofstede and Boddewyn, 1977). Our aim in this paper is to explore the impossible, the unattainable and for that stories are very suitable indeed, as they do not "complete or 'exemplify' a thought, [but rather] produce a further searching” (Stewart, 1996, p. 32).

\section{Methods}

We conducted a narrative study in three stages, aimed at identifying strong plots pertaining to systemic change. Strong plots are ideas popular and mass culture which, through their popularity and persuasive power, are able to influence social practice (Czarniawska and Rhodes, 2008). They are significant vehicles in structuring 
thinking and defining options which appear available for understanding and dealing with complex problems (Kociatkiewicz and Kostera, 2016), and a limited repertoire of strong plots hampers the ability to explain and address institutional crises (Czarniawska, 2012).

The analysed material came from three different sources of narratives and was approached by the use of two different narrative methods. We shall present the methods in this section after having briefly addressed our general approach.

Ours is a broad narrative perspective, assuming organizing and institutional structuring depend on processes of sensemaking (Weick, 1995), and that the cultural construction of reality is constantly interwoven with storytelling (Czarniawska 1999). Stories are both illuminating and practical as research method and object, and can be used in many different ways, from collection in the field, via interpretation, to creative storytelling. Following Barbara Czarniawska and Carl Rhodes (2008), we believe that research can successfully make use of writings of all genres and kinds. Plots, and strong plots, can be found in many types of narratives. According to Hayden White (1973) emplotment is a form of narration that carries meaning: the content is "translated" in the reading process depending on the type of main plot. The link between the plot and the kind of story is not binding but typical, creating coherence and making the tale understandable for the reader. Hayden White argues that linguistic coherence depends on style - readers perceive something as coherent because it is written in a coherent style.

The main object of our study is plot and style of narrative of three types: fiction from sci-fi literature, news from mass media, and, finally, creative accounts authored by respondents. The method used for the study of stories found in fiction and the media, is based on the interpretive approach favoured by Pierre Guillet de Monthoux and Barbara Czarniawska-Joerges (1994): thematic reading focused on the relationship between symbolism and plot. We considered the narratives open works, in Umberto Eco's (1989) understanding: texts which invite the reader to be "an active center for an unlimited net of relationships, whom he is to give an own shape, not being limited by a compulsion implied by the given rules of organization of a given text" (p. 28). Our goal was to capture and present elements of text corresponding with a main plot marking "the history that human beings make and live spontaneously is determined by structures of meaning that they have not chosen for themselves" (Denzin, 1992, p. 74). This is a reading that takes into consideration a broad material but focuses on elements regarded as meaningful, revealing of broader cultural plot construction: an approach associated with symbolic interactionism (Blumer, 1969). The presentation in this paper is limited to selected plots and symbols of interest considering: 1) the topic, 2) the role they play, in our critical post factum reading, in meaning making in the relevant period of time.

The method we used for the study of creative narratives is one based on creative stories and called narrative collage (Kostera, 2006). Instead of focusing on intersubjective data, the collage aims at catching the individual and imaginary, even if it sometimes, as in this case, refers to real events and results in realistic accounts. The role of the researcher is reminiscent of the role of an artist or an editor. He or she invites a group of people, selected on purpose because of their role in the social interactions or with regards to the studied idea, to write short stories on a given topic or beginning with a given phrase. The collage is not representative of any realistic social setting, rather, it is an excursion into people's sensitivity and imagination. Everyone would do the collage differently. Another person, interested in similar things, and partial to similar methods, would collect different stories and suggest different topics. Each study of this kind is unique, just as each visual arts event is unique and every theatrical performance is different, even if repetitive. The main advantage of this method is an ability to glimpse into the subjective sphere; it is an active call for outliers, poetic moments shared in storyform. It is particularly beneficial when adopted as a method of insight into the ambiguous, non-obvious, in-the-making and not yet crystallized cultural processes. We believed it would be a good method to study such a unique and extraordinary event as the fall of state communism in Poland 1989.

\section{Science fiction: When reality fails}

In order to explore the theme of systemic failure, we carried out a study of science fiction literature in search of a theme of a failure of the dominant reality, system, or paradigm. The plots we focused on spoke of the confrontation with the impossible, of reacting 
to extraordinariness and the fall of the seemingly most reliable institutions is one of the main themes reappearing throughout the science fiction literature, thus making it a natural place to look for insights into the situation of sudden reality withdrawal. From a vast repository of books, we selected twelve which, in our opinion, best represented the kind of plot we were interested in. The stories we reference here form, thus, by no means a complete list of those pertinent to the issue, they are included rather as examples of the ways of approaching the problem of facing the impossible in the science fiction genre. We have chosen the ones we find the most enlightening in the context of making sense of the fall of a large social system, though of course this choice involved a considerable amount of discretion. Our estimate of their literary qualities, though it might be relevant to their persuasiveness and possible influence, did not play a part in our choice. We have consciously excluded publications from the last twenty years, as we wanted to focus not on the science fictional response to, or reflection of, the ongoing collapse, but rather an overview of varied approaches to the general problem of reality collapse. We will now briefly outline the plots as well as some of the dominant symbols.

All of the plots depicted shock. The reasons behind such a shock can be most varied, ranging from lifechanging technological advances, like in George Alec Effinger's When Gravity Fails (1986), referencing life in orbital stations (and a Bob Dylan song in which the phrase originated), to the drug-induced hallucinations of Philip K. Dick's (1964/1990) The Three Stigmata of Palmer Eldritch to stepping into an alternate universe in Andre Norton's (1963) Witch World. We explored the books, looking for the subplots and symbols explaining how people react to the unknown and the unexpected.

There are not one but many plots, a multitude of responses to the intrusion of impossibility. We would like to take a look at a few of the symbolic reactions we find the most significant and promising in our attempt to understand the plot of reality failure.

The first one is the one of wonder at all the possibilities opening up due to the arrival of the impossible, possibly accompanied by the relief at seeing all the old worries turning obsolete and unimportant. Such is the case in Samuel Delany's (1966/92) Empire Star, where Jo, a teenage boy from a backward planet starts a journey through the whole known universe on an unexpected errand, discovering in the process that reality is much more complex (or, as the author would have it - "multiplex") than he could have anticipated. An interesting aspect of this revelation is the realisation of the manifold perspectives contributing to the perceived world (this is how the word "multiplexity" is used in this novel), as well as a diffusion of any certainties and absolute judgements that the hero used to hold about the universe in general.

Another way of looking at the sudden change in available possibilities is to notice all the business opportunities opening up because of the paradigm shift. This plot is represented by a film producer L.M. Greenspan in Harry Harrison's (1967/94) Technicolor Time Machine. The novel seems somewhat ironic in describing the commercial use of a time machine in film-making (producing a cheap but epic Hollywood historical kitsch), although the producer's attitude in itself is quite realistic: a window of opportunity has opened itself. A more far-reaching account is presented in Iain M. Banks' (1996) Excession, where a discovery of an artifact of highly advanced technology has numerous civilizations vying for the power it might offer.

In many plots, the end of the established reality threatens to displace the old way of living and encounters a strong polarity in the characters' attitude towards changes. The heroes and heroines tend to consider their options, to compare and contrast. On the one hand, there is an eagerness in embracing the impossible as typified on by Daniel Chain from Roger Zelazny's (1980/89) Wizard World, who steps into a fantasy world and finds it much more to his liking than the twentieth century he has just left, even though his life up till then was not too miserable. On the other, there is Thomas Covenant (Donaldson, 1977/80), who, in a similar situation, remains hesitant if not averse, seeing the change as an obstacle in coping with the problems he had in the old, "real” world - and yet, his situation there used to be pretty miserable.

Furthermore, some plots signal an uncertainty as to which reality should be perceived as more valid, or more „real”. Disbelief in one form or another is common subplot, either complete as in Thomas Covenant's case, or partial, like that of Arthur Dent (Adams, 1979/93), who, seeing the destruction of Earth, can easily accept 
the end of New York but not of McDonald's. Cyril M. Kornbluth (1950/85) adds yet another twist to the plot of disbelief what contradicts the accepted reality - in his short story The Silly Season a long series of apparently absurd events reported by various newspapers causes humans to ignore the news of a Martian invasion until it is far too late.

Finally, some plots address the possibility of undramatic changes - strange things happen, and we, the readers know about it, but they pass largely unnoticed by the book's protagonists. This is what takes place in Harry Harrison's (1991) The View from the Top of the Tower, where the only recipient of an alien race's desperate attempt at contacting earth is a drunk neither willing nor able to do anything about these revelations. Sometimes the characters remain calm despite the impossible events taking place all around, like the Russian townsfolk in Kir Bulytchev's (1982) short story, easily accepting an alien spacecraft crash in their backyard as an event of little or no consequence.

\section{Media: The new order}

\section{News of the shift}

First, let us take a look at some mass media symbols and plots marking the moment of the shift. We studied the daily Gazeta Wyborcza, launched as a news outlet for the anti-communist opposition before the first postWorld War II democratic elections in June 1989. We studied the paper's volume of that year, i.e. beginning with June and ending December 1989. The first and most dominating plot, with a multitude of suitable symbols, was that of transition. This is not a shock, but a moment of passage. The issue dated 1989, June 4th, or the election day, published a short statement signed by Lech Wałęsa, containing among others, the following phrase:

$$
\begin{aligned}
& \text { [...]this is not yet freedom and democracy, but it } \\
& \text { is an important step towards a free, democratic, } \\
& \text { economically sane Poland (Wałęsa, 1989, p. 1) }
\end{aligned}
$$

The front page also contains an instruction about how to technically vote, so that the voting ticket will be considered valid, and an article by Józef Tischner, a Catholic oppositionist priest and philosopher, declaring that he intends to vote, praising democratic values, courage, and the public good. Gazeta Wyborcza of June 5th, 1989, was beginning to reflect the realization of the triumph of the opposition:
[...] Solidarność, by organizing and carrying through a successful campaign, has proved that it is a great social power. This is the common work of those who had organized this campaign, those who had supported it in different ways, those who manifested an interest in it, and those, or perhaps, in the first place, those who voted for Solidarność. They will be rewarded through the results of the elections (Gazeta Wyborcza, 1989a: 1).

Another article from the front page explains that the votes are still being counted, but the preliminary unofficial results "put [us] in a very optimistic mood” (Gazeta Wyborcza 1989b: 1). On June 6th it was already more or less certain and almost official: Solidarność has won the elections, within the limits set in the preceding negotiations. Leading activists of the opposition speak of a victory - and of responsibility in Gazeta Wyborcza, of that date. Still, this is definitely a plot of transition, of a passing through between two stable states. Adam Michnik, the editor-in-chief, in an article about the elections entitled „Joy... and a moment of reflection” (Michnik, 1989: 1), says:

Thank you, dear friends. Thanks to all who helped Solidarność with the campaign. It is thanks to you, tens of thousands of anonymous friends from every part of Poland that we won the campaign and the elections.

He recognizes the importance of the moment:

the day of June 4th will be remembered as a Polish day of celebration. The Polish people voted for hope (p. 1).

It is only the beginning of something new, as durable (at least), as the past, which has now become history. Further, the in-chief speaks of the important to build an institutional order under difficult circumstances "the geopolitical position of Poland has not [...] changed, and the ones managing the apparatus of coercion have not changed" (p. 1). June 4th is the day beginning the „endeavor of all supporters of the idea of an evolutionary transformation from the Stalinist communist system to parliamentary democracy" (p. 1).

None of this news explicitly talks about changing reality, and this is representative of the studied period. It is true, however, that the very existence of the paper, as well as the authors and politicians it featured, was a symbol 
not of transition but of a sudden and remarkable shift: from the mass media nothingness of blacklisted names and political programmes, to a self-evident witness to a dramatic metamorphosis taking place at that time in Poland.

\section{The new obvious}

This situation changed rapidly after that fateful year. Monika Kostera (1996) has studied the media discourse pertaining to the change in the identity of enterprises and managers taking place in Poland in the early 90-ties. She analyzed three papers, including Gazeta Wyborcza, looking for symbols and plots of the new times. Her findings suggest the media were ten taking for granted that Western enterprises and managers were heroes, one-sided images of perfection, which only some Polish enterprises have come close to imitating. Western categories such as "success" and "free market" were presented as obvious and the only viable alternative. The plot of the "Polish version of the American dream" appeared to be in use very often, in the news as in feature articles. Stories about Western organizations and managers were as one-sided as the Polish contrasting examples: they were simple and with a plain moral. The Western examples were successful because they were what they were (Western and thus successful). Polish negative "background" examples were, similarly, a failure because they were as they were. The Polish positive examples were different, because they were not the image of perfection, and very often they are problematized: they narrated stories of problems and how they were overcome. The plots were much more simple and naive than the actual managerial responses to change, which were based on varying rationalities, often either continuing to work from the "old" communist times or composing a suitable mixture of "old" and "new" symbols and ideas (Kostera, 1995a). Choosing the "wrong" symbols was unthinkable: there is no acceptable image for alternative social actors.

In the mid-1990s (1994 and 1995), Monika Kostera (1996) asked MBA students and practicing managers, students of evening courses in management to react to the images of managers and of enterprises disseminated by the press in anonymous reviews. Typically, they reacted with open irony and distancing themselves from the images of the organizations, with very subtle, between-the-lines, irony to the symbolism and plotlines of the stories of organizations and managers. Most of them were "between-the-line” comments, ambiguous allusions rather than complete stories. This mode of sensemaking, characteristic of post-1989 Poland, extremely one-sided and depriving actors of a voice, has been depicted as a crusade (Kostera, 1995b), a plot transferring "truths" from the West to the East. The Western consultants act as missionaries of the old times, attempting to convert the Eastern "heathens" to the new faith of market economy. To this the Polish managers typically respond with private irony and public passivity.

\section{Popular tales: What the people saw}

We used a narrative collage method to see what kind of stories people tell about the shift of 1989 . We asked our informants, students of an MBA level course at a private business school in Warsaw, to author personal tales in any genre they preferred. The story collection took place in 1999.

Our respondents were persons of varied age (early 30 s to late 40 s), slightly more men than women, all working as managers, albeit of differing levels (middle to top management, a few CEOs and entrepreneurs). A colleague, teaching at the MBA programme, asked his students to write a short story about what, according to them, happened in 1989, in form of a short story. They had 30 minutes to accomplish the task. He promised them that the answers would be anonymous, which would encourage them to write more freely about possibly emotionally laden matters. Only one person signed his text. We received 24 texts in total.

None of the students wrote what we would call an elaborate text: full of symbols and non-straightforward characters. All chose the realistic autobiographic genre. We then analyzed the material and found that almost all narratives fit into one of four major plots, with a set of fairly typical symbols, which we will now describe. We have found only one non-typical text, which we will present later.

The first plot we called the cliché. It is typically a set of slogans, put together more or less swiftly into a narrative or semi-narrative with an obvious sense moral. Usually, it was added as a fast sub-plot to another, more central 
plot in the collected tales. The sometimes appeared as disconnected statements like this one:

The year of 1989 is a gate for me and for Poland and a chance for normalcy.

The phrase "normalcy” was used very often in the years 1989-1990 in the mass media to convey the message that Poland was now on the road to something normal, standard, not very revolutionary or remarkable, from having been „abnormal,” „sick,” „wrong." “The victory of ideas that I believed in; optimism and hope" — says another, repeating words and sentences we both have heard in the mass media innumerable times, like many other of the clichés, not elaborated or connected to the other plots in the story. It can also provide a link to a different narrative or an introduction:

It was for me the year of regaining of independence and the year of new hopes for better conditions of living,

The above is another sentence we recognize too well from the mass media, although in a slightly distorted version. The same applies to the following sentence, serving as an introduction to a "business story":

This year turned out to be the year of the retrieving of freedom for millions of beings from Central Europe, and especially from Poland.

The abundance of platitudes used by the respondents is remarkable, phrases once used extensively by media as metaphors communicating the change and its significance were embedded in sentences concerning the change itself.

The second plot is the nothing much happened story. It contains often personal recollections, sometimes very important, but with no connection to the outside world. "I decided to get married" — said one respondent.

In 1989, I was finishing ground school and had to choose the type of my further education $\neg[\ldots]$ the year of one of the greatest shift for me - I went to the gymnasium,

said another. Some recount trivialities:

That wasn't a year very different from any other. The family finances allowed us to keep a fair level of life [...] Generally quiet.

Some people state the insignificance of the year openly:

To be honest, I do not associate anything special to me personally with this year.
One respondent explains him- or herself, why s/ he doesn't believe that the year 1989 was anything significant $-s /$ he was only 19 , and too young to be interested in politics. The explanation keeps to a logic internal in the story, it is no objective truth: we know many people who were and are actively interested in politics at the age of 19 , and younger.

The personal narratives refer to the private domain, explicitly and implicitly disconnected from the systemic shift. Some of these tales have cliché subplots, whereas others do not.

The third plot we called the business opportunity narrative. It is a story of how significant the year 1989 was to the person's economy or how the person made use of the opportunity it presented. Typically, these stories contain much detail and often include feelings and relationships. One person begins with an opening reminding the cliché stories, but it develops then into a case study, quite typical of this kind of narrative:

That was a time of great change for the individuals who wished to lead their own businesses. My father together with my uncle established a firm that started as a service enterprise and developed to a trade enterprise. In the beginning, there were just them two, and the rest of the family occasionally being asked (or ordered) to help out. Once, I was just a school kid then. I got woken up in the night by my father looking panicked: son, you must help me, we have lost an order. The customer is waiting for his order and I can't find it...

The story presents the adventure of starting a family business in quite some detail. Another student talks about the "changes in the ways of communication within the company - talking aloud about privatization" and continues with a description of a privatization process of the state owned company he was managing. One person tells his story of working abroad in 1989 and how he was disconcerted at first by the change - it made the value of his laboriously earned dollars much less significant than under communism, but how he then realized that it was, after all, a favorable change:

Looking from the perspective of the time [that passed], the changes that arrived with the year of 1989 turned out, in my case, beneficial.

He explains that he now 
leads [his] own company, and the incomes from the company are higher than the incomes that [he] would have got from physical labor abroad.

One respondent tells her own powerful business story:

In 1989 I stopped working in a large firm with a decidedly communist approach to work, people, sales etc. and I started my own construction firm employing 6 people + a part-time employed book keeper. I bought 2 concrete mixers, a few shovels, trowels, and I lead reconstruction works. It was scary, I had no experience, but had great enthusiasm.

The business opportunity plot seems to be the most engaging of the plots, and contains the most suspense.

The fourth plot is the transition story. Some respondents present a tale of the passage from one stable state to another, possibly with some reflection on how they were ambivalent in the beginning, but then realized how good the change was. Occasionally they made an implicit point that it is not okay to be reluctant towards the change:

The explosion of the new made me anxious at first.

It all happened so unexpectedly, it could mean that "people from the former system would be held responsible”, it could prove to be unstable, once again reversible, the respondent explains. Another person explains that the transition is not over yet:

Unfortunately, the hopes for better living conditions were not real for everyone. It turned out that again political cynicism, theft, and corruption entered the stage. But this period should be treated as a time of transition that will end in some time and the situation will be stabilized, as for example in the European Union to which we aspire.

Another respondent tells the story of her/his engagement in the shift, how s/he participated in the strike of April 1989, and how s/he was engaged in various political activities connected to the campaign and the elections. In a transition story full of platitudes and private recollections of trivialities, one respondent included the following capitalized sentence:

\section{PEOPLE SMILED MORE OFTEN AND WERE HAPPIER.}

This is an interesting story, because, even though, it uses the plot of transition between stable states as the main textual strategy, it contains so many other symbols and semi-plots. The last sentence, emphasized in the text, falls outside of the standard plotting but does not offer a plot by itself, it is, perhaps more of a poetic textual moment.

Another transition story contained a phrase that does not fit into either of the four plots very well, but was, too, extremely short and ambiguous:

For the first time I realized that the problems that concern me are important to many people in Poland.

This is a short semi-plot, as it sketches a development in time, but its significance is not easy to interpret. It may be one of the "nothing much" stories but it may also be something more than that, a statement about the recognition of the link between the person and society, a link severed under communism (Stefan Nowak, 1979 , coined the concept of the gap between the public and private spheres in communist Poland). If it is no intended to play that role, then it belongs to our last category of stories - the other tales.

In this last category, there was most definitely one poetic tale, which stood out among the tales in the batch, sketching a development, but being framed as a short poem rather than narrative:

The year of 1989 was to me

„The Great Unknown”???

\section{Making sense of the stories}

The difference between, on the one hand, the stories of the people and media, and, on the other, the science fiction plots, is quite striking. Most of the students narratives tend to trivialize the shift or write it out completely of the story (with the exception of the "business opportunity" plot and the one or two outstanding tales). The authors remember the fateful year, sometimes in quite detail, but present it as a year like every other, or a cliché, marking the shift in a way easily recognized from mass media, but failing to engage with it in any way. The outstanding story (or two) is no different in the latter respect - it pronounces a mystery to have happened but does not go into any details or address the occurrence. The "business opportunity" plots, however, tend to be quite elaborate, describing the different endeavours, the investments, the reactions of the market, and so on. In other words, these plots produced quite substantial stories, with details and nuances, sometimes also with feelings and characters. The interesting point to make here is, however, that in 
the students' tales the characters seemed to be endowed with more agency than the protagonists of similar science fiction tales. Another interesting similarity, this time between media accounts and science fiction tales, is the issue of transition between two stable states. The media testifying to the shift that we have studied, and the media reports after the shift, seem to be predominantly emplotted in this fashion. Science fiction books also contain such plots, but here the reader is observing this sense making mode taking place and presenting it as equally interesting and bizarre as the dramatic reality shift itself.

Science fiction and fantasy literature normalize the impossible, but it offers an emplotment suitable for wonder and enchantment. The feelings experienced by all the children drawn to the magical world of Narnia in C.S. Lewis' (1950/1985) classic novel series are not just emotional reactions to stories of wonder, but they reflect those of the characters of these novels, where they are narrated and expressed. Impossibility gains a language and, significantly, a plot. They fulfill an important role, as propose authors such as Czarniawska and Guillet de Monthoux (1994) and Philips (1995): as guides not just in the domain of the imagination, but in everyday reality, which is much more complex than many of our everyday plots allow. This is especially true of moments of systemic shift, such as the fall of state communism or today's interregnum. We would like to add that such moments reveal the particular appropriateness of science fiction as the genre most helpful in dealing with issues of social change, of mediation between the incommensurable alternatives, or of alteration from one alternative to another.

Furthermore, science fiction even offers a way of handling the "nothing much"/ transition between stable states reactions to change that dominates in the factual accounts. This type of plot allows for metareflection on the popular reflections. For example, in Robert Sheckley's (1966/95) Mindswap, the hero travels through rapidly changing and increasingly bizarre realities, and attempts to order and understand all the incomprehensible events taking place all around him through the use of genre templates that are available to him. He begins by seeing in the surreal worlds around him scenes from: (kitschy) western, romance, detective, and adventure stories. He is attentive and reflective, commenting what he sees and categorizing according to his best knowledge. Sometimes he even sees through his own categories and understand that this is not what is really happening around him, only fictional plots he lends in order to make sense of the impossible. However, the author lets the final change of reality catch the protagonist by surprise. At the end of the novel we find him in a dramatically altered copy of modernday planet Earth and he is oblivious to all the drastic changes that have taken place all around him. This is a turn of the plot very much like the nothing much stories; the hero has fallen into the same narrative snare as most of us in the face of the impossible. However, as readers of the book we gain a metalevel of reflection. We join the author in not only observing the final inability to emplot and narrate the impossible, but we also realize that we, too, have been doing exactly the kind of things that the protagonist engaged in before losing the plot: ascribing ready-made templates to the shifting reality. Of course, not even science fiction equips us for a language adequate for dealing with mystery and wonder, but such stories augment and parallel those presented in the narratives we have collected, forming together a richer repertoire of plots and symbols for understanding social change than the popular or media responses on their own.

The plot most sensitive to the magnitude of change in both the MBA students' stories and existent in science fiction seems to be the „business opportunity” plot. It is also reflected in research dating from the transition era, for example Andrzej K. Koźmiński (1993) tells of a multitude of new firms that emerged after 1989, as well as of new forms that the old ones begun to take, truly a "thousand flowers in bloom", to use a metaphor from another cultural context in a similar condition. This points to an interesting aspect of the so called transition in Poland, as argued by Krystyna Bolesta-Kukułka (1992) in her historiographic account of the Polish post World War II context of organizing: the existence of a parallel language and symbolism of entrepreneurship and business acumen, with the possible exception of the years of Stalin. This plot was there all the time, as if waiting for its chance to become one of the dominant. All characters ready to step into the role of entrepreneurs/ business people were able to use this emplotment, which was more or less ready-made. 


\section{Coda}

Les belles lettres, and in our study specifically science fiction, seems to be a genre of writing able to lend a language to talk about dramatic systemic change, periods in between relatively stable states. It is fundamentally important in order to find a footing shareable with others in times of the interregnum, which, as Zygmunt Bauman (2017) shows, is necessary so that we can avoid destructive retrotopian rhetorics and political tendencies. Furthermore, it also helps to explore different dimensions in social change, and especially the „empty space”, structural blanks between solid constructs, which is the crucial element of all reforms (Czarniawska-Joerges, 1993). These blanks can be inscribed by modes of interpretation and writing from the past (as if life continued as usual), by re-configurations of past experience, or by new experiments, and if we have a language to talk about all these alternatives, then there is more of a chance that the change will be creative and not just anything that seemed ready-made and available at the moment. The risk of such simplistic solutions increases when alternatives are not imagined and discussed. Discussing radical change with the aid of science fiction literature may help undertake mental and emotional experiments in how to make sense and use of the empty space - the period in between working systems when change can take place.

This proposition goes sharply against the contemporary trend to cut down on the humanities in contemporary university education (see e.g. Collini, 2012, for presentation and critique of this trend). We agree with authors suggesting that we will be needing (and already need) not less but much more influence from the humanities in social science education, and in particular, in management learning (a good example of such voices is: Gagliardi and Czarniawska, 2006). The business school has become "cash cows" for universities and, in the process, hijacked their mother institutions with their simplistic, highly ideologized and naïvely linear educational programmes and culture, argues Martin Parker (2018) in his Shut down the business school. This approach is, in the light of our musings presented in this paper, highly unhelpful to the task that humanity - and our organizations - are currently facing: facing the void of the interregnum and finding a system that will be more ecologically viable and more just, while not doing away with our culture and knowledge. We do not need education blinding us with illusions of simple solutions. If they persevere with this mission, then we agree with Martin Parker that business schools need to be shut down. Or else, as Parker says, they could be transformed into a radical alternative in the form of schools for organizing, that would develop and discuss different alternatives instead of reproducing the dominant model. Such schools could, we believe, with advantage base their education in much larger extent than until now, on programmes including the study of fiction and film (with a prominent presence of science fiction). For example, the educational programmes in management offered by the Institute of Culture at the Jagiellonian University in Poland (2019), contain large obligatory modules on art history, philosophy, history of culture - as well as more traditional modules, such as organization and management theory, marketing, etc. Another example of a management education with extensive emphasis on humanities is the Stockholm School of Economics Art Initiatives (2019). It is not an obligatory part of management education, but an institution suffusing the school's architecture, social life and educational philosophy. They organize numerous events and exhibitions which are not only free but impossible to miss for the students of the School. They also act as a platform for encounters between students, faculties and artists, encouraging dialogues and providing future and current managers with a language of the arts. We share the conviction of Pasquale Gagliardi (20006) that such an approach to education

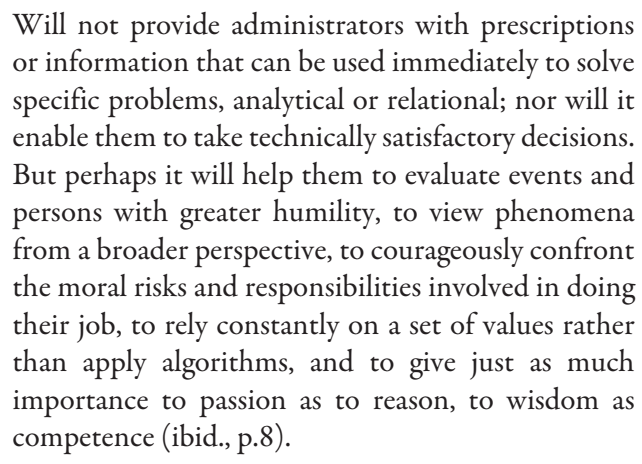

And that is precisely what we so much lack - and so desperately need in these times on interregnum. 


\section{References}

Adams, Douglas (1979/1993) The Hitchhiker's Guide to the Galaxy. London: Heinemann.

Banks, Iain M. (1996) Excession. London: Orbit.

Bauman, Zygmunt (2012) "Times of Interregnum." Ethics and Global Politics, 5/1:49-56.

Bauman, Zygmunt (2017) Retrotopia. Cambridge: Polity Press.

Blumer, Herbert (1969) Symbolic Interactionism: Perspective and method. Englewood Cliffs, NJ: Prentice Hall.

Boje, David M. (2001) Narrative Methods for Organizational and Communication Research. London: Sage.

Bolesta-Kukułka, Krystyna (1992) Gra o Wtadze a Gospodarka Polska 1944-1991. Warszawa: PWE.

Bruner, Jerome (1991) "The narrative construction of reality." Criticial Inquiry, 18(1): 1-21.

Bulytchev, Kiryl (1982) Retrogenetyka i Inne Opowiadania. Warszawa: Iskry.

Collini, Stefan (2012) What Are Universities for? London: Penguin Books.

Czarniawska, Barbara (2012) "New plots are badly needed in finance: Accounting for the financial crisis of 2007-2010." Accounting, Auditing \& Accountability Journal, 25(5): 756-775.

Czarniawska, Barbara and Carl Rhodes (2006) "Strong plots: The relationship between popular culture and management theory and practice", in: Pasquale Gagliardi and Barbara Czarniawska (eds) Management and Humanities. London: Edward Elgar, pp. 195-218.

Czarniawska-Joerges, Barbara (1993) The Threedimensional Organization: A constructionist view. Lund: Studentlitteratur.

Czarniawska-Joerges, Barbara (1995) "Narration or science? Collapsing the division in organization studies." Organization 2/1: 11-33.
Czarniawska-Joerges, Barbara and Pierre Guillet de Monthoux (1994) (eds.) Good Novels, Better Management: Reading organizational realities, Chur: Harwood.

Dark Mountain Project, The (2014) Uncivilization. Dark Mountain Books.

Delany, Samuel R. (1966/92) Gwiazda Imperium (Empire Star). Gdansk: Phantom Press.

Denzin, Norman K. (1992) Symbolic Interactionism and Cultural Studies: The politics of interpretation. Oxford: Blackwell.

Dick, Philip K. (1964/90) Trzy Stygmaty Palmera Eldritcha (The Three Stigmata of Palmer Eldritch). Poznan: Amber.

Donaldson, Stephen (1977/80) Lord Foul's Bane. Glasgow: Fontana.

Doors, the (1967) "The End", The Doors. Produced by Paul A. Rothchild.

Eco, Umberto (2000) Kant and the Platypus: Essays on language and cognition. London: Vintage.

Eco, Umberto (1989) The Open Work. (Opera aperta: Forma e indeterminazione nelle poetiche contemporanee). Cambridge: Harvard U.P.

Effinger, George Alec (1986) When Gravity Fails. New York: Baen Books.

Fleming, Peter (2017) The Death of Homo Economicus: Work, debt and the myth of endless accumulation. London: Pluto Press.

Gabriel, Yiannis (2000) Storytelling in Organizations: Facts, fictions, and fantasies. Oxford: Oxford University Press.

Gagliardi, Pasquale (2006) "A role for humanities in the formation of managers", in: Pasquale Gagliardi and Barbara Czarniawska (2006).

Gagliardi, Pasquale and Barbara Czarniawska (2006) (eds.) Management Education and Humanities. Cheltenham: Edward Elgar. 
Głowiński, M. (1992) Rytuat i Demagogia: Trzynaście szkiców o sztuce zdegradowanej (Ritual and Demagogy: Thirteen sketches on degraded art). Warszawa: Open.

Gramsci, Antonio (2005) Selections from the Prison Notebooks. London: Lawrence \& Wishart.

Harman, Chris (2009) Zombie Capitalism: Global crisis and the relevance of Marx. Chicago: Haymarket Books.

Harrison, Harry (1967/94) Filmowy Webikut Czasu (Technicolor Time Machine). Warszawa: Amber.

Harrison, Harry (1991) "Widok ze szczytu wiezy (The view from the top of the tower)." Nowa Fantastyka, 8(107):3-6.

Hofstede, Geert and Jean J. Boddewyn (1977) "Introduction: Power in organization." International Studies of Management and Organization, 7/1:3-7.

Institiute of Culture (2019) Programy Studiów. Retrieved on 20/2/2019 from https://kultura. uj.edu.pl/studia/programy-studiow

Klein, Naomi (2014) This changes everything: Capitalism vs. the climate. New York: Simon and Schuster.

Kociatkiewicz, Jerzy and Monika Kostera (2002) "When reality fails: Science fiction and the fall of communism in Poland." In: Mihaela Kelemen and Monika Kostera (eds.) Managing the Transition: Critical Management Research in Eastern Europe. Palgrave, pp. 217-238.

Kociatkiewicz, Jerzy and Monika Kostera (2016) "Grand plots of management bestsellers: Learning from narrative and thematic coherence." Management Learning 47(3): 324-342.

Kornbluth, Cyril M. (1950/1985) "The Silly Season" in: Sezon Ogorkowy. Warszawa: Iskry, pp. 7-20.

Kostera, Monika (1995a) "Differing managerial responses to change in Poland." Organization Studies, 16/4: 673-697,
Kostera, Monika (1995b) "The modern crusade: Missionaries of management come to Eastern Europe." Management Learning, 26/3: 331-352.

Kostera, Monika (1996) "The manager's new clothes: on identity transfer in post-1989 Poland." in: Monica Lee, Hugo Letiche, Robert Crawshaw i Michael Thomas (ed.) Management Education in the New Europe. Thomson Business Press, pp. 194-211.

Kostera, Monika (2006) "The Narrative Collage as Research Method." Storytelling, Self, Society, 2/2: 5-27.

Koźmiński, Andrzej K. (1993) Catching Up? Organizational and management change in the ex-socialist block. New York: State of New York University Press.

Le Guin, Ursula K. (1980) "It was a dark and stormy night; Or, why are we huddling about the campfire?" Critical Inquiry, 7/1: 191-199.

Lewis, Clive Staples (1950/1985) The Lion, the Witch, and the Wardrobe, London: Fontana

Michnik, Adam (1989) "Radość... i chwila namysłu." Gazeta Wyborcza, 21/1: 1.

Norton, Andre (1963) Witch World. New York: Ace Books.

Nowak, Stefan (1979) "System wartości społeczeństwa polskiego (The value system of the Polish society)." Studia Socjologiczne, 4: 155-173.

Parker, Martin (2018) Shut Down the Business School. London: Pluto Press.

Philips, Norman (1995) "Telling organizational tales: On the role of narrative fiction in the study of organizations." Organization Studies, 16/4: 625-649.

Sheckley, Robert (1966/95) Zwichrowany Swiat (Mindswap) Warszawa: Amber.

Stewart, Kathleen (1996) A Space on the Side of the Road: Cultural poetics in an "other" America. Princeton: Princeton University Press. 
Stockholm School of Economics Art Initiative (2019) SSE ART Initiative. Retrieved on 20/2/2019 from https://www.hhs.se/en/outreach/sseinitiatives/art-initiative/

Streeck, Wolfgang (2016a) How Will Capitalism End? Essays on a failing system. London: Verso.

Streeck, Wolfgang (2016b) "The post-capitalist interregnum: The old system is dying, but a new social order cannot yet be born." Juncture, 23/2: 68-77.

Wałęsa, Lech (1989) "Mili Panstwo! Drogi Wyborco!" Gazeta Wyborcza 19/1: 1.
Weick, Karl E. (1995) Sensemaking in Organizations. Thousands Oaks, CA: Sage.

White, Hayden (1973) Metahistory: The historical imagination in nineteenth-century Europe. Baltimore: John Hopkins University Press.

Yurchak, Alexei (2005) Everything Was Forever, Until It Was No More: The last Soviet generation. Princeton: Princeton University Press.

Zelazny, Roger (1980/1989) Wizard World. New York: Baen Books. 